\title{
Population genetic structure, coloration, and morphometrics of yellowhead jawfish Opistognathus aurifrons (Perciformes: Opistognathidae) in the Caribbean region
}

\author{
Adeljean L. F. C. Ho* ${ }^{*}$ Christin L. Pruett, Junda Lin \\ Department of Biological Sciences, Florida Institute of Technology, Melbourne, Florida 32901, USA
}

\begin{abstract}
We investigated intraspecific variability in phenotype and population genetic structure of yellowhead jawfish Opistognathus aurifrons from 4 different locations in the Caribbean region: South Florida (USA), Bimini (Bahamas), St. Thomas (US Virgin Islands), and Aruba. Discriminant function analysis (DFA) of 9 melanistic traits in the head region resulted in clear separation between Bimini and the other 3 populations. South Florida, St. Thomas, and Aruba slightly overlapped in patterning, with St. Thomas forming the transition between South Florida and Aruba. DFA of 17 morphometric characters elucidated differentiation among the 4 populations with some overlap between populations. Analysis of concatenated cytochrome $c$ oxidase subunit I (COI) and mitochondrial control region ( $\mathrm{mtCR}$ ) sequences revealed substantial differences among $O$. aurifrons populations (pairwise $\Phi_{\mathrm{ST}}=0.185-0.566$ ), although there was a lack of reciprocal monophyly. Differences in patterning and morphometrics constituted different phenotypes that predominated in each location, with high levels of genetic differentiation between sampled populations. Bimini was most divergent in phenotype, while Aruba was most divergent in genetics. As such, variations in phenotype and genetics are not congruent for $O$. aurifrons investigated in this study.
\end{abstract}

KEY WORDS: Caribbean Sea · Connectivity · Discriminant Function Analysis · Fish · Morphology · $\mathrm{mtDNA} \cdot \mathrm{mtCR} \cdot \mathrm{COI} \cdot$ Population genetics

\section{INTRODUCTION}

The degree of genetic connectivity and resulting genetic structure over a given geographic area is highly dependent on the species' realized dispersal given ecological and biogeographical barriers (Bohonak 1999, Palumbi 2003, Avise 2004, Trakhtenbrot et al. 2005). Marine fishes with longer pelagic larval durations (PLDs) are likely able to disperse into larger and more distant areas of settlement relative to those with shorter PLDs (Shanks 2009). Based on passive particle models, Roberts (1997) suggested that there is large-scale connectivity among many species across the Caribbean and adjacent seas, indicating that recruitment for a given area might be dependent on adjacent locales. As such, genetic homogeneity would be expected over vast distances (Warner 1997).

Although the abilities and behaviors of larval fishes (reviewed by Leis 2006), such as detection of terrestrial noise and chemical cues (Simpson et al. 2005, Dixson et al. 2008), extensive swimming abilities (Stobutzki \& Bellwood 1997), and vertical distribution (Cowen \& Castro 1994), can have large influ- 
ences on recruitment, oceanographic patterns on both the geographic and temporal scales can also contribute to recruitment processes (Cowen et al. 2000, Bradbury \& Snelgrove 2001, Schirripa \& Colbert 2006, Galarza et al. 2009). Longer PLDs can lead to extensive dispersal (Shanks 2009), and this could cause extensive gene flow and diminished levels of population genetic structure. However, PLD has been found to be only weakly correlated to and a poor predictor of population subdivision (Bowen et al. 2006a, Weersing \& Toonen 2009). In the presence of high potential for dispersal, adaptations to specific environments (Rocha et al. 2005) or color cues (Taylor \& Hellberg 2003) may lead to strong genetic structuring due to nonrandom mating. However, a series of studies on hamlets Hypoplectrus spp. found that even in the presence of assortative mating among many drastically different color forms, genetic structuring is weak or almost completely absent (McCartney et al. 2003, Ramon et al. 2003, Puebla et al. 2007).

Coloration in animals has important ecological functions and has been the focus of much research (e.g. Seehausen \& van Alphen 1998, Hanlon et al. 2010). However, our understanding of the processes leading to specific patterning is still limited. In model organisms, specific genes that can result in mutant or aberrant color forms have been identified (Iwashita et al. 2006, Watanabe et al. 2006), and more complex melanistic patterns can develop from pre-existing patterns by means of co-optive expression of a morphogen at new sites (Werner et al. 2010). In addition to patterning and coloration, animals are known to display morphometric variability. These variations may provide an adaptive advantage in which certain body shapes are more aptly suited for certain tasks or environments. Variability in morphology can occur on both interspecific (Clabaut et al. 2007) and intraspecific levels (Cutwa \& Turingan 2000), and are subject to being phenotypically plastic or genetically fixed (Scheiner 1993).

The yellowhead jawfish Opistognathus aurifrons (Jordan \& Thompson 1905) is a colonial opistognathid that inhabits sandy and coral debris substrate (Leong 1967, Colin 1971) and ranges across the wider Bahamas and Caribbean region (Colin 1972, 1973, Walder 1975). These fish construct burrows in rubbly sediment for shelter (Leong 1967, Colin 1972, 1973). This feature and the blue-yellow coloration make $O$. aurifrons a popular species in the marine ornamental fish trade (Wabnitz et al. 2003), for which only wild-caught specimens are available. With the threat of commercial exploitation and other negative anthropogenic impacts, there is a need to identify and conserve intraspecific diversity of the species (Millar \& Libby 1991, Waples 1995).

Like all reported opistognathids, Opistognathus aurifrons is a paternal oral brooder, and pelagic larvae are released at hatch (Leong 1967). Laboratory rearing has revealed that larvae become competent between 15 and 21 d post hatch (DPH; Young 1982, Wittenrich 2007, A. Ho unpubl. data). For demersal eggs, DPH is fundamentally equivalent to PLD, and based on passive particle advection velocities (Shulman \& Bermingham 1995, Taylor \& Hellberg 2003), $O$. aurifrons larvae can potentially disperse between 400 and $500 \mathrm{~km}$ per generation. Thus, there is a potential for long-range dispersal and a high degree of genetic connectivity among $O$. aurifrons populations. Although potential for long-range dispersal is present, Böhlke \& Thomas (1961) noted geographically linked differences in patterning and morphology, which can be indicative of genetic subdivision and local adaptation, although phenotypic plasticity and genetic drift cannot be ruled out. Böhlke \& Thomas (1961) attributed the differences among populations to reduced genetic exchange, although prior to our study, no one has examined the population genetics of $O$. aurifrons.

Understanding the genetic structure and morphological attributes of a population(s) for a given species is crucial to aid in our understanding of dispersal patterns, genetic connectivity, and the process of speciation. The goals of this study were to (1) characterize the structure of melanistic patterning, (2) characterize morphological structure, (3) characterize genetic structure, and (4) determine whether there is a correspondence between melanistic patterning, morphological structure, and genetic structure in Opistognathus aurifrons.

\section{MATERIALS AND METHODS}

\section{Sampling}

Opistognathus aurifrons were collected from the following 4 locations between the months of June and August 2009: South Florida, USA $\left(24.983^{\circ} \mathrm{N}\right.$, $80.420^{\circ} \mathrm{W}$ (Key Largo) and $25.715^{\circ} \mathrm{N}, 80.098^{\circ} \mathrm{W}$ (Key Biscayne, Miami)); Bimini, Bahamas $\left(25.590^{\circ} \mathrm{N}\right.$, $\left.79.315^{\circ} \mathrm{W}\right)$; St. Thomas, US Virgin Islands $\left(18.318^{\circ} \mathrm{N}\right.$, $\left.64.990^{\circ} \mathrm{W}\right)$; and Aruba (12.852 ${ }^{\circ} \mathrm{N}, 70.057^{\circ} \mathrm{W}$; Fig. 1). Fresh muscle tissue for genetic analysis was stored at $-80^{\circ} \mathrm{C}$, while specimens were fixed in $10 \%$ formalin and subsequently stored in $70 \%$ ethanol. 


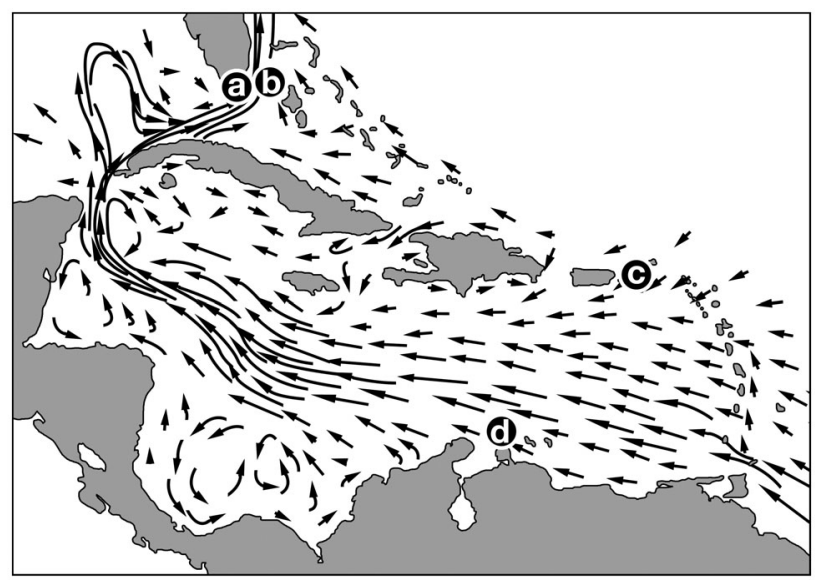

Fig. 1. Planimetric map of western Atlantic and Caribbean illustrating sampled sites: (a) South Florida, USA, (b) Bimini, Bahamas, (c) St. Thomas, US Virgin Islands, and (d) Aruba (see 'Materials and methods' for latitudes and longitudes). Major surface current patterns adopted from Roberts (1997), where arrow tail length is roughly proportional to current strength

\section{Melanistic patterning}

Formalin fixation and ethanol storage does not alter or degrade melanistic patterning in Opistognathus aurifrons (Böhlke \& Thomas 1961), and samples were analyzed for melanistic patterning after fixation. Preliminary analysis of all collected samples revealed various melanistic characters that differed among the populations. We examined 7 melanistic traits in the head region (Table 1). Due to potential asymmetry, both left and right laterals of traits 1 to 6 were measured, resulting in 13 traits in total.

Specimens were thus scored for each of the 13 melanistic traits, and these traits were subjected to discriminant function analysis (DFA) using PASW Statistics 18.0.0 (SPSS) with the a priori groups South
Florida $(\mathrm{n}=44)$, Bimini $(\mathrm{n}=9)$, St. Thomas $(\mathrm{n}=31)$, and Aruba $(n=30)$, for a total sample size of $N=114$. Prior to running the DFA, traits entered were subjected to a tolerance test. Traits (left branchiostegal ray dusking, right preoperculum edging, right operculum edging, and eye band) failing the tolerance test were excluded from the DFA in order to guard against matrix ill-conditioning. In addition to assessing grouping based on a priori expectations (location of origin), groupings based on sex and sexual maturity (juveniles/adults) were investigated across and within each a priori group. Sample size for Bimini was substantially smaller than that for the other 3 locations due to sample availability.

\section{Morphology}

Seventeen morphometric characters were measured following Böhlke \& Thomas (1961) and Helfman et al. (2009), with modifications to suit the species in question (Table 2). We measured each fixed specimen with a Vernier caliper to $0.05 \mathrm{~mm}$ accuracy. Additionally, we measured standard length (SL) and 17 morphometric characters expressed as a fraction of SL. Subsequent to morphological analyses, we identified sex by gonadal inspection. Specimens where sex allocation was unclear were assumed to be juveniles and were excluded from further morphometric analysis to eliminate potential effects of ontogenetic shifts in morphometrics. Thus, sample size for morphometric analysis is less than the number of specimens collected. Seventeen morphometric characters were subjected to DFA with the a priori groups South Florida $(\mathrm{n}=32)$, Bimini $(\mathrm{n}=7)$, St. Thomas $(\mathrm{n}=25)$, and Aruba $(\mathrm{n}=30)$, for a total sample size of $\mathrm{N}=94$ and an approximately equal ratio of males to females in each group (see Table S1 in Supplement 1, available at www.int-res.com/

Table 1. Opistognathus aurifrons. Description of 7 observed melanistic traits that were divided into ordinal categories and subjected to discriminant function analysis

Trait

Description

No. ordina categories

1 Chin \& gular spots

2 Gular band

3 Preoperculum edging Operculum edging Maxillary band Branchiostegal ray dusking Eye band
Spots to the anterior and posterior of the gular folds when mouth is closed Bands and or spots in the gular folds that are visible only when the buccoopercular cavity is expanded and the gular folds are stretched out

Edging of preoperculum

Edging of operculum

Line in maxillary groove

Dusking of branchiostegal rays

Band connecting eyes over the back of the head 
Table 2. Opistognathus aurifrons. Description of 17 morphometric characters subjected to discriminant function analysis

\begin{tabular}{|c|c|c|}
\hline & Character & Description \\
\hline a & Premaxilla-maxilla length & Distance between snout and back end of maxilla \\
\hline $\mathrm{b}$ & Premaxilla-preopercular length & Distance between snout and central corner of the preoperculum \\
\hline $\mathrm{C}$ & Premaxilla-midopercular length & $\begin{array}{l}\text { Distance between snout and operculum at the height of ventral notch in the } \\
\text { operculum }\end{array}$ \\
\hline $\mathrm{d}$ & Premaxilla-dorsoopercular length & Distance between snout and dorsal corner of the operculum \\
\hline e & Maxilla-dorsoopercular length & Distance between bottom of maxilla and dorsal corner of the operculum \\
\hline $\mathrm{f}$ & Maxilla width & Maximum width of maxilla \\
\hline g & Premaxilla-eye length & Distance between snout and back of eye \\
\hline $\mathrm{h}$ & Eye width & Width of eye across the tear-drop axis \\
\hline i & Dentary-gular pad length & Distance between tip of dentary and forward crease of the central gular pad \\
\hline j & Dentary-branchiostegal fold length & $\begin{array}{l}\text { Distance between tip of dentary and crossing of the folded branchiostegal } \\
\text { membrane }\end{array}$ \\
\hline $\mathrm{k}$ & Predorsal length & Distance from tip of premaxilla to dorsal fin origin \\
\hline 1 & Preanal length & Distance from tip of premaxilla to anal fin origin \\
\hline $\mathrm{m}$ & Pectoral fin length & Length of median pectoral ray \\
\hline $\mathrm{n}$ & Caudal fin length & Length of median caudal ray \\
\hline o & Caudal peduncle depth & Depth of caudal peduncle \\
\hline $\mathrm{p}$ & Pelvic depth & Depth at origin of pelvic fin \\
\hline $\mathrm{q}$ & Anal depth & Depth at origin of anal fin \\
\hline
\end{tabular}

articles/suppl/m444p275_supp/). All 17 characters passed the tolerance test. In addition to assessing grouping based on a priori expectations, grouping based on sex was investigated across and within each a priori group.

\section{Genetics}

We used a Qiagen DNeasy blood and tissue kit to extract and purify total genomic DNA from muscle tissues. We then used polymerase chain reaction (PCR) with methods based on Kocher et al. (1989) to amplify 2 mitochondrial markers: 5' end of the mitochondrial control region (mtCR) and cytochrome $C$ oxidase subunit one (COI) using primer pairs CR-A and CR-B (Lee et al. 1995) and FishF2 and FishR2 (Ward et al. 2005), respectively. Amplification was conducted with Fisher BioReagents* exACTGene* Core Reagents Set B (Thermo Fisher Scientific) in the following solution: $50 \mu \mathrm{l}$ of solution containing $5 \mu \mathrm{l}$ PCR Buffer B $(10 \times), 2.5 \mu \mathrm{l}$ of each primer $(10 \mu \mathrm{M})$, $2.5 \mu \mathrm{l}$ of bovine serum albumin $\left(10 \mathrm{mg} \mathrm{ml}^{-1}\right), 3 \mu \mathrm{l}$ of $\mathrm{MgCl}_{2}(25 \mu \mathrm{M}), 1 \mu \mathrm{l}$ of dNTP (10 mM each), $0.25 \mu \mathrm{l}$ of Taq DNA polymerase $\left(5 \mathrm{U} \mathrm{\mu l}^{-1}\right), 5 \mu \mathrm{l}$ of template DNA, and $28.25 \mu \mathrm{l}$ of ultrapure water. Conditions for the PCR were an initial denaturation step of 5 min at $95^{\circ} \mathrm{C}$, followed by 30 cycles of denaturation at $94^{\circ} \mathrm{C}$ for $1 \mathrm{~min}$, annealing at $55^{\circ} \mathrm{C}$ for $1 \mathrm{~min}$, and extension at $72^{\circ} \mathrm{C}$ for $2 \mathrm{~min}$, and terminated with a final extension cycle of $10 \mathrm{~min}$ at $72^{\circ} \mathrm{C}$. Amplified products were purified by means of precipitation with $45 \mu \mathrm{l}$ of $20 \%$ polyethelene glycol in $2.5 \mathrm{M} \mathrm{NaCl}$, washed twice with $80 \%$ ethanol, dried, and resuspended in $20 \mu \mathrm{l}$ of ultrapure water. Purified products were sequenced at the University of Florida using an Applied Biosystems Model 3130 Genetic analyzer. Subsample sizes of $\sim 15$ were randomly selected from the pool of collected specimens, across adults of both sexes and juveniles (Rosenberg \& Nordborg 2002). Sample sizes for both markers from each geographic location were $\mathrm{n}=15$ for South Florida, $\mathrm{n}=9$ for Bimini, $\mathrm{n}=14$ for St. Thomas, and $\mathrm{n}=15$ for Aruba for a total sample size of $\mathrm{N}=53$.

We assembled and edited sequences using Sequencher 4.8 (Gene Codes Corporation) and aligned sequences using an internet implementation of ClustalW2 set to default parameters (www.ebi.ac.uk/ Tools/clustalw2/). A partition homogeneity test (Farris et al. 1994) was implemented with PAUP* $4 \mathrm{~b} 10$ (Swofford 2003) between the COI and mtCR and with a heuristic search using 10000 random repartitions. The signals were found to be congruent $(\mathrm{p}=$ 0.124 ), and sequences were subsequently concatenated for further analyses. Tajima's $D$ test (Tajima 1989), Fu and Li's $D^{*}$ test (Fu \& Li 1993), Fu's $F_{S}(\mathrm{Fu}$ 1997), and Ramos-Onsins and Rozas' $R_{2}$ test for deviations from neutrality against population growth (Ramos-Onsins \& Rozas 2002) were conducted using DnaSP 5.10.01 (Librado \& Rozas 2009) and tested for significance with coalescent simulations with 10000 permutations. To test for population expansion, mis- 
match distribution analysis (Rogers \& Harpending 1992) was employed with the sum-of-squareddifference statistic (SSD) to test for conformity of the observed to the expected distribution under a model of sudden population expansion (Rogers 1995), and tested for significance using 10000 parametric bootstrap replicates in Arlequin 3.11 (Excoffier et al. 2005). The Hasegawa-Kishino-Yano nucleotide substitution model $\left(\mathrm{HKY}+\mathrm{I}+\mathrm{G}_{\text {; }}\right.$ Hasegawa et al. 1985) with proportion of invariant sites $(I)$ of 0.347 and gamma shape parameter $(G)$ of 0.29 was identified and optimized using the Bayesian information criterion approach in jModelTest 0.1.1 (Posada 2008). We conducted an analysis of molecular variance (AMOVA, Excoffier et al. 1992) using an external distance matrix extracted from PAUP* using the model identified by jModelTest with 10100 permutations to test for significance. Contingent on results of AMOVA, population pairwise $\Phi_{\mathrm{ST}}$ values were calculated and tested for significant deviation from 0 with 10100 permutations, with a standard Bonferroni correction (Rosenthal \& Rubin 1984). We used Arlequin (Excoffier et al. 2005) to conduct these analyses. MrBayes 3.1 (Ronquist \& Huelsenbeck 2003) was employed to develop a phylogeny using the HKY+I+G nucleotide substitution model (Hasegawa et al. 1985) and allowed to estimate the $I$ and $G$ components. The trees were rooted with 2 congeners: Opistognathus macrognathus and $O$. robinsi. The analysis was conducted with 2 runs of 3000000 generations and trees sampled every 100 . Topologies of the 2 runs were similar, and after $25 \%$ burn-in, a consensus tree consisting of 44875 trees from the 2 runs was constructed using TreeView 1.6.6 (Page 1996). Polymorphic sites were determined using DnaSP 5.10.01, and these sites were used to construct an unrooted median-joining haplotype network using Network 4.6.0.0 (Bandelt et al. 1999).

\section{RESULTS}

\section{Melanistic patterning}

Although equal sample sizes are not required for discriminant analyses, increased discrepancy in sample size lowers the effectiveness of distinguishing between groups (McGarigal et al. 2000). Nonetheless, ordination and grouping results were robust and allowed for clear interpretation (for both melanistic patterning and morphometrics to follow). DFA resulted in the first canonical function accounting for $70.8 \%$ of the variance and the second for $29.1 \%$ with a total of $99.9 \%$ of the variance explained. The first canonical function loaded heavily $(-0.5<$ coefficients $>0.5$ ) for right maxillary band and left gular band on the positive axis and left maxillary band on the negative. The second canonical function also loaded heavily for left gular band on the positive axis, but for right maxillary band on the negative axis (Table S2 in Supplement 1). Differences in melanistic patterning were sufficient to permit a high degree of discrimination among the 4 geographic locations, with over $92 \%$ of specimens correctly classified (Table S3 in Supplement 1). The first function discriminated primarily between Bimini and the 3 remaining locations (Fig. 2). Biminian specimens showed the highest level in melanistic patterning with all traits recorded scoring $\geq$ category 2 . However, both first and second functions were required to discriminate among the 3 remaining sites (South Florida, St. Thomas, and Aruba), which formed a slightly overlapping continuum in patterning, with St. Thomas forming a bridge between Florida and Aruba. All South Florida specimens lacked any melanistic patterning, showed no variability in patterning, and coalesced in 1 point. Specimens from Aruba and St. Thomas were highly variable in patterning, and Aruba specimens showed melanistic patterning only in the gular folds and included complete bands, broken bands, and small spots (Fig. 3). St. Thomas specimens showed very limited melanistic patterning confined to the gular folds, with predominantly 2 spots at the anterior end of the gular

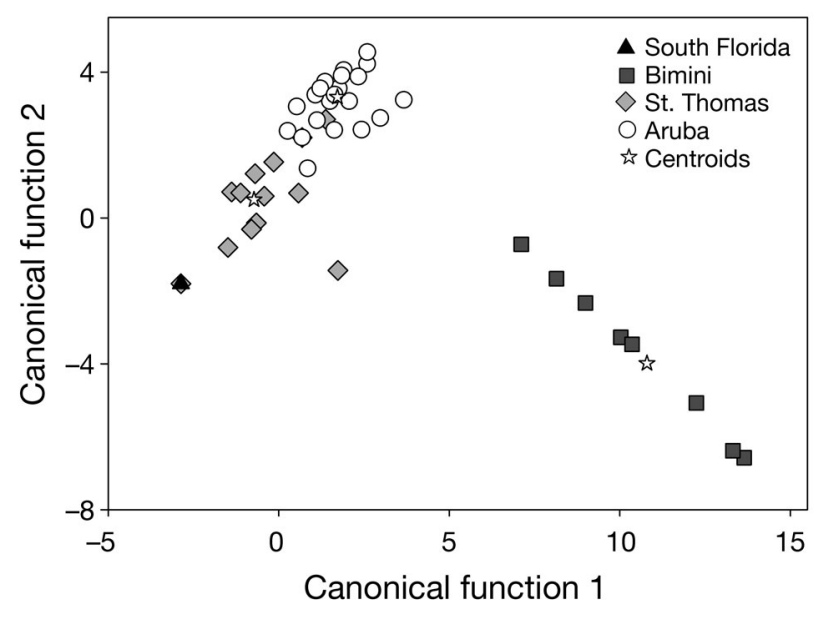

Fig. 2. Opistognathus aurifrons. Relative positions in plots of the first 2 canonical functions of specimens collected from 4 geographic locations and subjected to discriminant function analysis of melanistic patterning. Centroid for South Florida omitted, because these specimens displayed no variability in patterning 

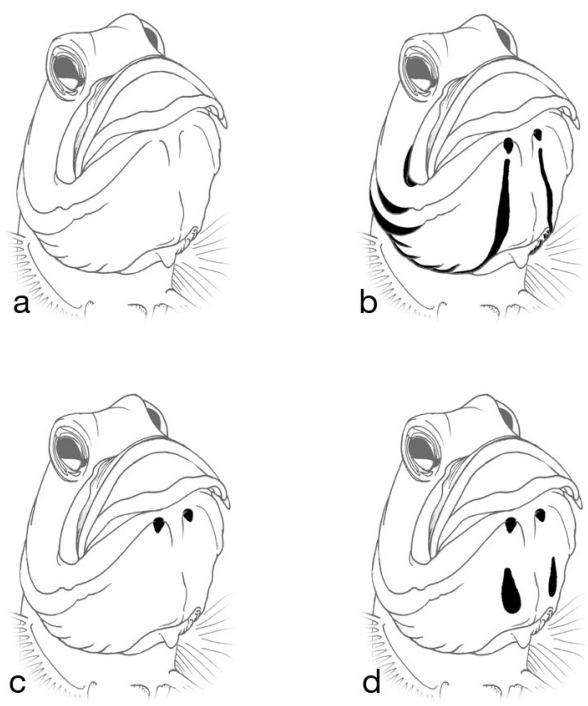

Fig. 3. Opistognathus aurifrons. Representative melanistic patterns encountered in each geographic location. (a) South Florida, (b) Bimini, (c) St. Thomas, and (d) Aruba. Note that patterns provided for a given geographic location are not mutually exclusive in reference to other locations. Aruba and St. Thomas specimens were variable in melanistic patterning, and illustrated patterns represent specimens ordinated close to group centroid

folds. Some St. Thomas specimens lacked any melanistic patterning and resembled Florida specimens. We also examined ordination of sexes and sexual maturity within the 2-dimensional space, but no discernable pattern was observed within or between locations (data not shown).

\section{Morphology}

DFA of morphometric characters resulted in $100.0 \%$ of the total variance explained by the first 3 canonical functions: $42.2 \%$ for the first, $32.3 \%$ for the second, and $25.5 \%$ for the third. The first canonical function loaded heavily $(-0.5<$ coefficients $>0.5)$ for maxilla width and eye width on the negative axis and premaxilla-dorsoopercular length on the positive. The second canonical function loaded heavily for premaxilla-eye length on the positive axis and anal depth on the negative. Lastly, the third function loaded heavily for pelvic depth and dentary-gular pad length on the positive axis and caudal fin length on the negative (Table S4 in Supplement 1). Although all locations exhibited a high degree of variability, differences in morphometric characters were sufficient to permit a high degree of discrimination among the 4 geographic locations, with over $89.9 \%$ of the specimens correctly classified (Table S3). All 3 functions ordinated in 3-dimensional space were required to discriminate among the 4 sites (Fig. 4). A video clip of the 3-dimensional display (Supplement 2) is available at www.int-res.com/articles/ suppl/m444p275_supp/. We also examined the ordination of sexes within 3-dimensional space for each $a$ priori group. No discernable pattern was observed (data not shown).

\section{Genetics}

A $650 \mathrm{bp}$ region of the COI and a $379 \mathrm{bp}$ region of the $\mathrm{mtCR}$ were amplified. The 2 loci were found to be congruent $(p=0.124)$ and were concatenated. From the concatenated sequences, 137 polymorphic sites were identified that contributed to 53 haplotypes; no haplotypes were shared among individuals (Table 3). Sequences for both loci have been deposited in GenBank. The accession numbers for
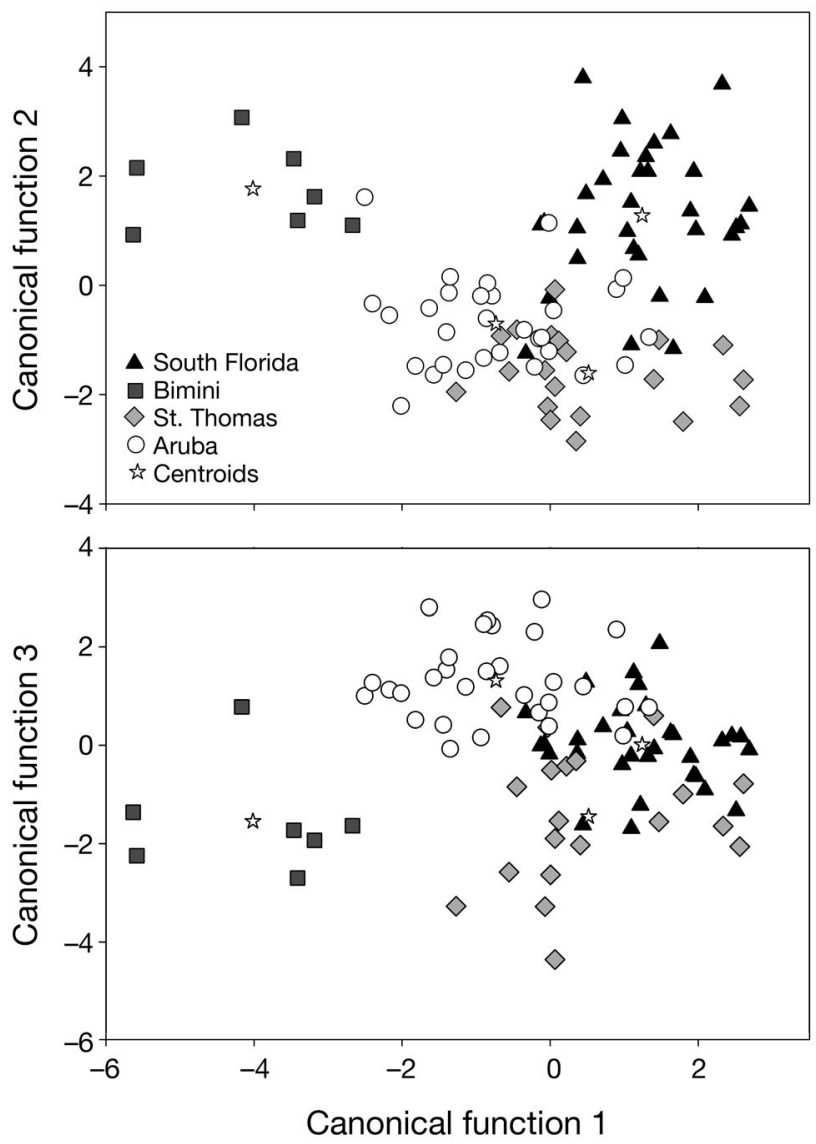

Fig. 4. Opistognathus aurifrons. Relative positions in plots of first 2 canonical functions (top) and first and third canonical functions (bottom) of specimens collected from 4 geographic locations and subjected to discriminant function analysis of morphometrics 
Table 3. Opistognathus aurifrons. Analysis of polymorphisms of concatenated $\mathrm{COI}$ and $\mathrm{mtCR}$ sequences in 4 populations. $h$ : haplotype diversity; $S$ : number of polymorphic (segregating) sites; Eta: number of mutations; Eta(s): total number of singleton mutations; $\pi$ : nucleotide diversity; $k$ : average number of nucleotide pairwise differences

\begin{tabular}{|lccrrrrrr|}
\hline Population & $\begin{array}{c}\text { Sample } \\
\text { size }\end{array}$ & $h$ & $S$ & Eta & Eta(s) & $\pi$ & $k$ \\
\hline South Florida & 15 & 1.000 & 43 & 45 & 25 & 0.01007 & 10.362 \\
Bimini & 9 & 1.000 & 47 & 47 & 35 & 0.01360 & 13.944 \\
St. Thomas & 14 & 1.000 & 52 & 56 & 21 & 0.01625 & 16.703 \\
Aruba & 15 & 1.000 & 81 & 86 & 25 & 0.02584 & 26.590 \\
Total & 53 & 1.000 & 137 & 161 & 51 & 0.02820 & 28.903 \\
\hline
\end{tabular}

Opistognathus aurifrons are JF297840 to JF297892 for COI and JF297893 to JF297945 for mtCR (Table S5 in Supplement 1). The accession numbers for $O$. macrognathus are JN193388 and JN193390, and for O. robinsi are JN193389 and JN193391 (COI and mtCR, respectively). Concatenated sequences did not significantly deviate from a neutral model of evolution using Tajima's $D$ test and Fu and Li's $D^{*}$ tests (Table S6 in Supplement 1). However, South Florida was found to deviate significantly using both Fu's $F_{S}$ and Ramos-Onsins and Rozas' $R_{2}$, while Aruba, Bimini, and St Thomas were found to deviate significantly by either Fu's $F_{S}$ or Ramos-Onsins and Rozas' $R_{2}$. Furthermore, mismatch distributions for all populations and pooled data did not detect any significant differences between the observed and expected distribution under a model of sudden population expansion (Table S6).

As revealed by AMOVA, 46.02\% of variance was significantly partitioned among populations for the concatenated COI and mtCR loci (i.e. $\Phi_{\mathrm{ST}}=0.4602$; among $\mathrm{SSD}=410.4, \mathrm{~V}_{\mathrm{a}}=9.59, \mathrm{df}=3,52, \mathrm{p}<0.0001$ based on 10100 permutations). All pairwise $\Phi_{\mathrm{ST}}$ values deviated significantly from 0 at $\mathrm{p}<0.0005$ level after Bonferroni correction. A substantial degree of differentiation was observed among all populations, with Bimini to St. Thomas showing the smallest amount $\left(\Phi_{\mathrm{ST}}=0.185\right.$; Table 4$)$, although comparisons

Table 4. Opistognathus aurifrons. Matrix of pairwise $\Phi_{\mathrm{ST}}$ values for concatenated COI and mtCR loci. Statistical significance of observed values of pairwise $\Phi_{\mathrm{ST}}$ was tested by comparison with 10100 generated permutations of genotypes of populations. ${ }^{*} \mathrm{p}<0.0005$ after Bonferroni correction

\begin{tabular}{|lccc|}
\hline & South Florida & Bimini & St. Thomas \\
\hline Bimini & $0.317^{*}$ & - & \\
St. Thomas & $0.384^{*}$ & $0.185^{*}$ & - \\
Aruba & $0.566^{*}$ & $0.468^{*}$ & $0.506^{*}$ \\
\hline
\end{tabular}

with Bimini need to be drawn with caution due to lower sample size $(\mathrm{n}=$ 9). The highest degree of differentiation was observed between Aruba and the other 3 populations $\left(\Phi_{\mathrm{ST}}=\right.$ 0.468 to 0.566 ; Table 4 ). This is visualized in the Bayesian phylogram by the majority of specimens from Aruba clustering outside of the rest of the localities (Fig. 5) and in the median joining network by 46 nucleotide substitutions between the main Aruba cluster and the other populations (Fig. 6). The topology of the phylogram was highly similar to the haplotype network. Three specimens from Aruba and 1 from South Florida clustered with other locations (Figs. 5 \& 6). Bimini and St. Thomas displayed multiple intermixed clusters, with 1 cluster sharing specimens from both Bimini and St. Thomas (Figs. 5 \& 6).

\section{DISCUSSION}

\section{Melanistic patterning}

In accordance with Böhlke \& Thomas (1961) and Walder (1975), melanism in Opistognathus aurifrons was found to vary with geographic origin. The most pronounced differences observed in the present study were between South Florida specimens that lacked any melanistic patterning and Bimini specimens that were heavily patterned, consistent with the findings of Böhlke \& Thomas (1961). Not surprisingly, these 2 color forms were characteristic of type specimens of $O$. aurifrons and Gnathypops bermudezi (Howell-Rivero 1936; species deemed invalid, and synonymized with $O$. aurifrons by Böhlke \& Thomas 1961). Aruba and St. Thomas specimens formed slightly overlapping groups. Furthermore, we found that some St. Thomas specimens were identical in melanistic patterning to South Florida specimens, supporting the findings of Böhlke \& Thomas (1961) that US Virgin Island specimens are intermediate to specimens from Florida and the Bahamas. With the additional Aruba location in our study, it is evident that the color form of Aruban specimens is intermediate to those of St. Thomas (US Virgin Islands) and Bimini (Bahamas; Fig. 3). Although there is some overlap in ordination for melanistic patterning, the DFA scatter plot and high degree of correct classification by predictive DFA support the presence of differences in melanistic patterning among populations. 

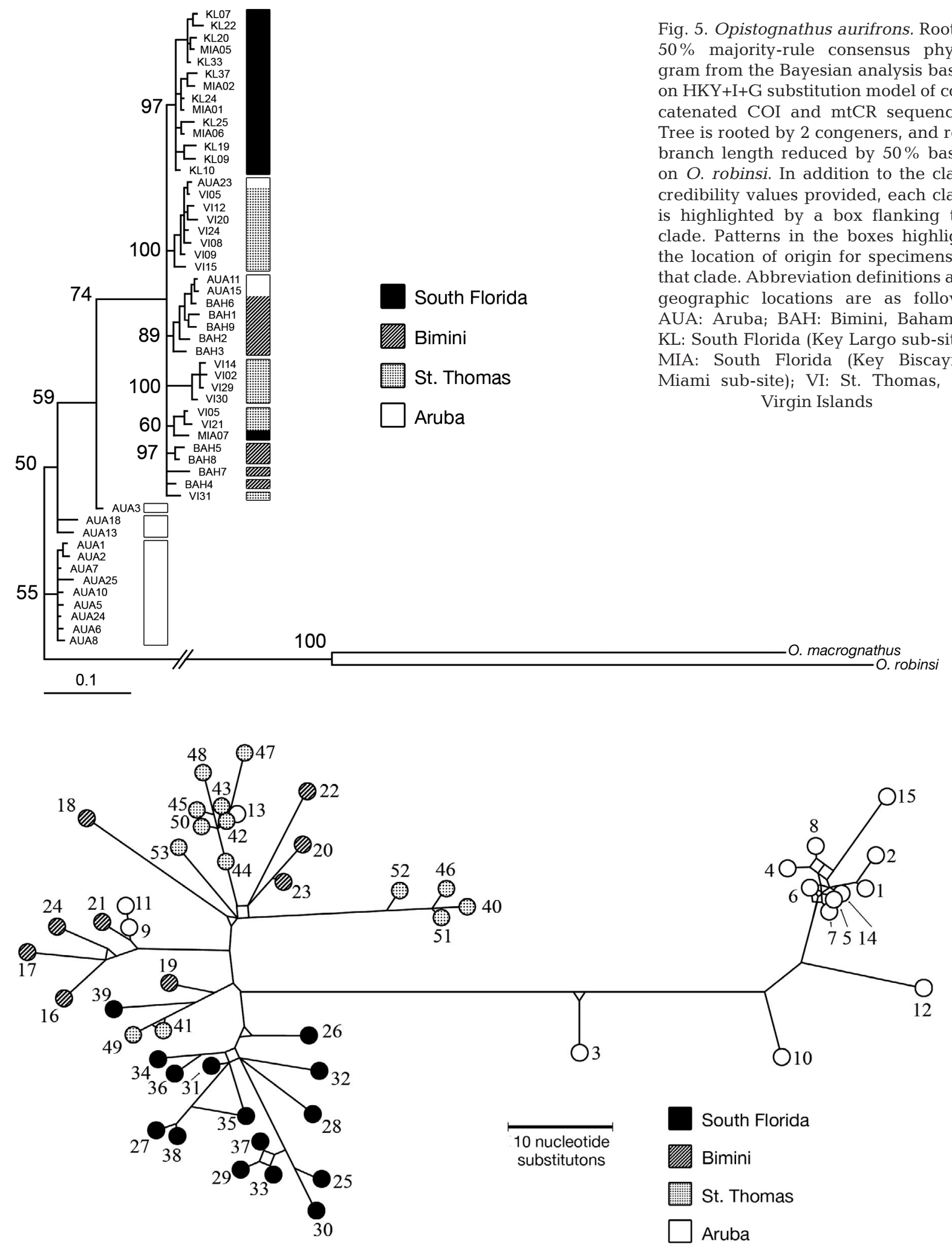

Fig. 6. Opistognathus aurifrons. Unrooted median joining haplotype network based on concatenated COI and mtCR sequences. Haplotypes represented by circles, with all sampled individuals $(n=53)$ exhibiting a unique haplotype. Shading of circles represents geographic origin of specimens. Lengths of branches are proportional to number of nucleotide substitutions. Haplotypes are numbered adjacent to circles or indicated with aid of arrows and refer to Table S2 in Supplement 1 (available at www.int-res.com/articles/suppl/m444p275_supp/) 
Coloration in animals has been shown to serve many functions, including mate recognition (Seehausen \& van Alphen 1998) and warning signals (Schuler \& Roper 1992, Marples et al. 2005). Melanistic patterning observed in Opistognathus aurifrons was limited to the head region. Head pigmentation, in particular factors that loaded heavily in the DFA, viz. gular and maxillary bands, in all specimens with the exception of those from Bimini, would only be effectively visible during agonistic displays, courtship displays, and brooding in males (Colin 1972, Walder 1975). Consequently, these markings may serve as a means of signaling (Colin 1972). For example, during courtship displays, the urohyal and hyoid complex are stretched down (Colin 1972) as the male curls around the female; in reciprocity, the female acknowledges the male's advances by also stretching down the urohyal and hyoid complex (DeLoach \& Humann 2007). The markings are clearly visible during these actions and could serve to function as a mate selection criterion either as female choice with genetic correlation (Lande 1980) or by means of mutual selection of the ornamentation (Kraaijeveld et al. 2007). In contrast, Walder (1975) proposed that melanistic markings observed in Bimini specimens are used as a defense mechanism by flashing the head markings (agonistic displays described by Cott 1966 [as cited by Walder 1975], Colin 1972).

\section{Morphology}

Morphometrics are useful in discriminating among the 4 sampled populations, although overlap between locales was evident. Unlike melanistic patterning, the apparent divergence of Bimini specimens with respect to the other sampling locations is not as pronounced (Fig. 4). Thus, one can infer proportional and incomplete differentiation between the 4 sampled locales. Considering that premaxilladorsoopercular length was the major contributing character on the positive axis (coefficient $=0.996$ ), South Florida fish have proportionally larger heads compared to specimens from Bimini. Aside from proportionally smaller heads, Bimini specimens showed a widening of the maxilla (negative axis). Although sexual dimorphism in jaw morphology is present among jawfishes (Smith-Vaniz 1972, Anderson \& Smith-Vaniz 1976, Hess 1993), no dimorphism was observed in this or a previous study (Hess 1993) for Opistognathus aurifrons. Unlike some fishes that dig burrows using their bodies (e.g. snakeblenny Lumpenus lampretaeformis: Atkinson et al. 1987), O. au- rifrons excavates exclusively with its mouth (Colin 1973). The observed differences in head size and morphology are likely reflective of their burrowing capacity, or the capacity to manipulate a particular substratum, i.e. rubble or soft sediment, and not oral incubation, as large broods have been observed to spill out of the oral cavity (A. Ho pers. obs.). Furthermore, a wider maxilla might serve to increase robustness of the jaw apparatus or provide additional support for articulation of existing elements to the benefit of burrowing activities. However, what aspects of the burrowing behavior or environmental conditions are driving these morphometric differences are unclear, as is the nature of this variability, i.e. whether it is a plastic response. Nonetheless, osteological and biomechanical studies would aid in elucidation of specific functions, if any, of observed differences in morphometrics.

\section{Genetics}

We found high levels of genetic diversity as expected given that mtCR is known to have high levels of substitution rates among teleosts (Alvarado Bremer et al. 1995, Nesbø et al. 2000, Bargelloni et al. 2003, Domingues et al. 2005). A comprehensive view of AMOVA and pairwise $\Phi_{\mathrm{ST}}$, phylogram, and haplotype network analyses for the concatenated sequences showed marked diversity and genetic structure among Opistognathus aurifrons populations.

Although the Aruba melanistic morph is very similar to the South Florida and St. Thomas morphs, the main genetic break was observed between Aruba and the other 3 locations, South Florida, Bimini, and St. Thomas. The geographic distance between Aruba and other locales along with the Caribbean current may be serving as a barrier; however, the Aruba haplotypes 9, 11, and 13 are far outside the Aruba lineage (see Fig. 6) and suggest recent dispersal events. A second genetic break was observed between South Florida and the 3 remaining sites. Although it has been suggested that the Gulf Stream may form a barrier for larval transport across the Straits of Florida, this is not always the case (Paris et al. 2005, Rocha et al. 2005), in particular with haplotype 39 located outside the South Florida branch. Nonetheless, genetic subdivision across the Straits of Florida has been noted in slippery dick Halichoeres bivittatus and has been attributed to ecological partitioning into subtropical (Florida) and tropical (Bahamas) habitats (Rocha et al. 2005), and provides an alternate scenario for the divergence of Opistognathus aurifrons across 
South Florida and Bimini. Bimini and St. Thomas exhibited significant differentiation (although $\Phi_{\mathrm{ST}}$ was lower in contrast to the other locations pairs), and a potential barrier to ongoing gene flow between these locales would be the Mona Passage, reflective of what has been observed in Elacatinus (Taylor \& Hellberg 2006). Accordingly, the 4 locations of $O$. aurifrons examined constitute 4 populations that are, to a greater or lesser degree, genetically isolated with evidence of low levels of migration.

The marine fish diversity of the Caribbean has been largely influenced by recent dispersal but also by historical biogeographic processes (Floeter et al. 2008, Lessios 2008), and genetic structure observed in the present study partly conforms to recent dispersal events in particular in light of support for a model of sudden population expansion, with an arguable exception of Aruba. Although Tajima's D and Fu and Li's $D^{*}$ tests suggest that the concatenated sequences for all populations are neutral, Fu's $F_{S}(\mathrm{Fu} 1997)$ and Ramos-Onsins and Rozas' $R_{2}$ tests, which are more powerful (Ramos-Onsins \& Rozas 2002), support either a selective sweep or recent population expansion (Table S6). The analysis of mismatch distributions resulted in SSD values that were not significantly different from expected unimodal distributions under a model of sudden population expansion ( $p>0.42$ for all distributions), even though there is a large divergence between Aruba the other populations. Analysis of mismatch distributions is known to be highly conservative (Ramos-Onsins \& Rozas 2002).

The genetic structure observed over short $(\sim 100 \mathrm{~km})$ and long $(>1500 \mathrm{~km})$ distances in this study is in sharp contrast to some other species with similar life histories as Opistognathus aurifrons. Populations of Azores chromis Chromis limbata over the extent of the Azores, Canaries, and Madeira (eastern Atlantic islands) exhibit a comparable geographic distribution to the distribution of the sampling sites in this study, yet very little genetic structure was encountered with almost complete homogenization across the archipelagos (Domingues et al. 2006). Similarly, C. multilineata, which is ubiquitous across the Caribbean and Southern Atlantic, shows similar patterns to $C$. limbata in the Caribbean, but shows marked structure across the Caribbean and Southern Atlantic basins (Rocha et al. 2008). However, Atlantic pygmy angelfishes Centropyge spp. that exhibit distinct coloration patterns associated with distinct geographies across the Caribbean and Southern Atlantic are genetically homogenous, at least mitochondrially (Bowen et al. 2006b). Nevertheless, our findings are similar to those found in Elacatinus spp., where over short distances marked genetic structure is observed and coincides with morphological differences (Taylor \& Hellberg 2003, 2006). The sharknose goby Elacatinus evelynae exhibits multiple color forms, and abrupt boundaries occurred around the islands of the Bahamas and between Puerto Rico and the Virgin Islands. Genetic structure and PLD ( 22 d) observed in E. evelynae show that even with lack of geophysical barriers, mate recognition characters can rapidly evolve as long as larvae are retained over successive generations (Taylor \& Hellberg 2003). Drastic differences in coloration appear to be able to evolve extremely fast. Hamlets Hypoplectrus spp. exhibit distinct color morphs and are known to mate assortatively (Puebla et al. 2007), although mitochondrially, Hypoplectrus are unresolved and suggestive of recent speciation (McCartney et al. 2003, Ramon et al. 2003). If observed patterning differences observed in $O$. aurifrons do serve as mate recognition characters, then it is probable that polymorphisms in genes controlling patterning are driving phenotypic differences, even though mitochondrial loci were incompletely sorted (Palumbi et al. 2001, Avise 2004).

\section{Congruence}

Close geographic proximity of South Florida to Bimini compared to St. Thomas and Aruba is contrasted by differences in color patterning, and to some degree morphology among the populations. The degree of phenotypic variation is disproportionate to the degree of genotypic variation (e.g. Aruba specimens were more divergent in genotype but intermediate in phenotypic morph). This lends support to the premise that melanistic phenotype in Opistognathus aurifrons is labile and thus unlikely to be useful for developing a phylogeny.

Nonetheless, results of DFA revealed marked differentiation between the sites studied (South Florida, Bimini, St. Thomas, and Aruba) based on analysis of both melanistic patterning and morphometrics. Marked genetic structure was found for all 4 sites studied. High levels of differentiation and 4 morphs based on melanistic patterning and morphometrics indicate that each population is distinctive, although not completely, as overlap in phenotypes was observed. Bimini exhibited the most melanification, while Aruba was most divergent in genetics (pairwise $\Phi_{\mathrm{ST}}$, phylogram, and haplotype network). As such, variations in phenotype and genetics are not proportional and are incongruent for Opistognathus aurifrons investigated in the present study. 
Acknowledgements. We thank B. Backus, C. Baker, N. Baker, C. Boleman, B. Burke, F. Franken, J. Turner, and M. Wittenrich for help in collecting/providing the fish specimens; N. Pham for editorial comments; and 4 anonymous reviewers who greatly improved the quality of this work. Specimens were collected following Institutional Animal Care and Use Committee protocol (FIT-090403) under permit number SAL-09-1156-SR for Florida with permission from the Florida Keys National Marine Sanctuary to collect within its boundaries; permit number STT-037-09 for St. Thomas; and a permit with no number for Aruba.

\section{LITERATURE CITED}

Alvarado Bremer JR, Baker AJ, Mejuto J (1995) Mitochondrial DNA control region sequences indicate extensive mixing of swordfish (Xiphias gladius) populations in the Atlantic Ocean. Can J Fish Aquat Sci 52:1720-1732

Anderson W, Smith-Vaniz W (1976) Sexual dimorphism in the jawfish Opistognathus melachasme. Copeia 202-204

> Atkinson R, Pelster B, Bridges C, Taylor A, Morris S (1987) Behavioural and physiological adaptations to a burrowing lifestyle in the snake blenny, Lumpenus lampretaeformis, and the red band fish, Cepola rubescens. J Fish Biol 31:639-659

Avise J (2004) Molecular markers, natural history, and evolution. Sinauer, New York, NY

Bandelt HJ, Forster P, Röhl A (1999) Median-joining networks for inferring intraspecific phylogenies. Mol Biol Evol 16:37-48

Bargelloni L, Alarcon JA, Alvarez MC, Penzo E, Magoulas A, Reis C, Patarnello T (2003) Discord in the family Sparidae (Teleostei): divergent phylogeographical patterns across the Atlantic-Mediterranean divide. J Evol Biol 16: 1149-1158

Böhlke JE, Thomas LP (1961) Notes on the West Atlantic jawfishes, Opistognathus aurifrons, O. lonchurus, Gnathypops hermudezi. Bull Mar Sci 11:503-516

Bohonak AJ (1999) Dispersal, gene flow, and population structure. Q Rev Biol 74:21-45

Bowen BW, Bass AL, Muss A, Carlin J, Robertson DR (2006a) Phylogeography of two Atlantic squirrelfishes (Family Holocentridae): exploring links between pelagic larval duration and population connectivity. Mar Biol 149: 899-913

> Bowen BW, Muss A, Rocha LA, Grant WS (2006b) Shallow mtDNA coalescence in Atlantic pygmy angelfishes (genus Centropyge) indicates a recent invasion from the Indian Ocean. J Hered 97:1-12

> Bradbury IR, Snelgrove PVR (2001) Contrasting larval transport in demersal fish and benthic invertebrates: the roles of behaviour and advective processes in determining spatial pattern. Can J Fish Aquat Sci 58:811-823

> Clabaut C, Bunje PME, Salzburger W, Meyer A, Schwenk K (2007) Geometric morphometric analyses provide evidence for the adaptive character of the Tanganyikan cichlid fish radiations. Evolution 61:560-578

Colin PL (1971) Interspecific relationships of the yellowhead jawfish, Opistognathus aurifrons (Pisces, Opistognathidae). Copeia 469-473

Colin PL (1972) Daily activity patterns and effects of environmental conditions on the behavior of the yellowhead jawfish, Opistognathus aurifrons with notes on its ecology. Zoologica 57:137-169
Colin PL (1973) Burrowing behavior of the yellowhead jawfish, Opistognathus aurifrons. Copeia 84-90

Cott HB (1966) Adaptive coloration in animals. Methuen and Co., London

Cowen RK, Castro LR (1994) Relation of coral reef fish larval distributions to island scale circulation around Barbados, West Indies. Bull Mar Sci 54:228-244

Cowen RK, Lwiza KM, Sponaugle S, Paris CB, Olson DB (2000) Connectivity of marine populations: open or closed? Science 287:857-859

Cutwa MM, Turingan RG (2000) Intralocality variation in feeding biomechanics and prey use in Archosargus probatocephalus (Teleostei, Sparidae), with implications for the ecomorphology of fishes. Environ Biol Fishes 59: 191-198

DeLoach N, Humann P (2007) Reef fish behavior: Florida, Caribbean, Bahamas. New World Publications, Jacksonville, FL

> Dixson DL, Jones GP, Munday PL, Planes S and others (2008) Coral reef fish smell leaves to find island homes. Proc R Soc Lond B Biol Sci 275:2831-2839

> Domingues VS, Bucciarelli G, Almada VC, Bernardi G (2005) Historical colonization and demography of the Mediterranean damselfish, Chromis chromis. Mol Ecol 14:4051-4063

Domingues VS, Santos RS, Brito A, Almada VC (2006) Historical population dynamics and demography of the eastern Atlantic pomacentrid Chromis limbata (Valenciennes, 1833). Mol Phylogenet Evol 40:139-147

Excoffier L, Smouse PE, Quattro JM (1992) Analysis of molecular variance inferred from metric distances among DNA haplotypes: application to human mitochondrial DNA restriction data. Genetics 131:479-491

Excoffier L, Laval G, Schneider S (2005) Arlequin (version 3.0): an integrated software package for population genetics data analysis. Evol Bioinform Online 1:47-50

Farris JS, Källersjö M, Kluge AG, Bult C (1994) Testing significance of incongruence. Cladistics 10:315-319

Floeter S, Rocha L, Robertson D, Joyeux J and others (2008) Atlantic reef fish biogeography and evolution. J Biogeogr 35:22-47

Fu YX (1997) Statistical tests of neutrality of mutations against population growth, hitchhiking and background selection. Genetics 147:915-925

> Fu YX, Li W (1993) Statistical tests of neutrality of mutations. Genetics 133:693-709

Galarza JA, Carreras-Carbonell J, Macpherson E, Pascual M, Roques S, Turner GF, Rico C (2009) The influence of oceanographic fronts and early-life-history traits on connectivity among littoral fish species. Proc Natl Acad Sci USA 106:1473-1478

Hanlon RT, Watson AC, Barbosa A (2010) A 'mimic octopus' in the Atlantic: flatfish mimicry and camouflage by Macrotritopus defilippi. Biol Bull (Woods Hole) 218: $15-24$

- Hasegawa M, Kishino H, Yano T (1985) Dating of the human-ape splitting by a molecular clock of mitochondrial DNA. J Mol Evol 22:160-174

Helfman G, Collette B, Facey D, Bowen BW (2009) The diversity of fishes: biology, evolution, and ecology. Wiley-Blackwell, Malden, MA

Hess HC (1993) Male mouthbrooding in jawfishes (Opistognathidae): constraints on polygyny. Bull Mar Sci 52: 806-818

Howell-Rivero L (1936) Some new, rare and little-known 
fishes from Cuba. Proc Boston Soc Nat Hist 41:41-76

Iwashita M, Watanabe M, Ishii M, Chen T and others (2006) Pigment pattern in jaguar/obelix zebrafish is caused by a Kir7.1 mutation: implications for the regulation of melanosome movement. PLoS Genet 2:e197

Jordan DS, Thompson JC (1905) The fish fauna of the Tortugas archipelago. Bull Bur Fish 24:229-256

> Kocher TD, Thomas WK, Meyer A, Edwards SV, Pääbo S, Villablanca FX, Wilson AC (1989) Dynamics of mitochondrial DNA evolution in animals: amplification and sequencing with conserved primers. Proc Natl Acad Sci USA 86:6196-6200

> Kraaijeveld K, Kraaijeveld-Smit FJL, Komdeur J (2007) The evolution of mutual ornamentation. Anim Behav 74: 657-677

> Lande R (1980) Sexual dimorphism, sexual selection, and adaptation in polygenic characters. Evolution 34: 292-305

> Lee WJ, Conroy J, Howell WH, Kocher TD (1995) Structure and evolution of teleost mitochondrial control regions. J Mol Evol 41:54-66

> Leis JM (2006) Are larvae of demersal fishes plankton or nekton? Adv Mar Biol 51:57-141

Leong D (1967) Breeding and territorial behaviour in Opisthognathus aurifrons (Opisthognathidae). Naturwissenschaften 54:97

> Lessios H (2008) The great American schism: divergence of marine organisms after the rise of the Central American Isthmus. Annu Rev Ecol Evol Syst 39:63-91

Librado P, Rozas J (2009) DnaSP v5: a software for comprehensive analysis of DNA polymorphism data. Bioinformatics 25:1451-1452

> Marples NM, Kelly DJ, Thomas RJ (2005) Perspective: the evolution of warning coloration is not paradoxical. Evolution 59:933-940

- McCartney MA, Acevedo J, Heredia C, Rico C, Quenoville B, Bermingham E, McMillan WO (2003) Genetic mosaic in a marine species flock. Mol Ecol 12:2963-2973

McGarigal K, Cushman S, Stafford S (2000) Multivariate statistics for wildlife and ecology research. Springer-Verlag New York, NY

Millar C, Libby W (1991) Strategies for conserving clinal, ecotypic, and disjunct population diversity in widespread species. In: Falk DA, Holsinger KE (eds) Genetics and conservation of rare plants. Oxford University Press, Oxford, p 149-170

> Nesbø CL, Rueness EK, Iversen SA, Skagen DW, Jakobsen KS (2000) Phylogeography and population history of Atlantic mackerel (Scomber scombrus L.): a genealogical approach reveals genetic structuring among the eastern Atlantic stocks. Proc R Soc Lond B Biol Sci 267:281-292

Page RDM (1996) TreeView: an application to display phylogenetic trees on personal computers. Comput Appl Biosci 12:357-358

Palumbi SR (2003) Population genetics, demographic connectivity, and the design of marine reserves. Ecol Appl 13(Suppl 1):146-158

Palumbi SR, Cipriano F, Hare MP (2001) Predicting nuclear gene coalescence from mitochondrial data: the threetimes rule. Evolution 55:859-868

> Paris CB, Cowen RK, Claro R, Lindeman KC (2005) Larval transport pathways from Cuban snapper (Lutjanidae) spawning aggregations based on biophysical modeling. Mar Ecol Prog Ser 296:93-106

Posada D (2008) jModelTest: phylogenetic model averaging.
Mol Biol Evol 25:1253-1256

> Puebla O, Bermingham E, Guichard F, Whiteman E (2007) Colour pattern as a single trait driving speciation in Hypoplectrus coral reef fishes? Proc R Soc Lond B Biol Sci 274:1265-1271

Ramon ML, Lobel PS, Sorenson MD (2003) Lack of mitochondrial genetic structure in hamlets (Hypoplectrus spp.): recent speciation or ongoing hybridization? Mol Ecol 12:2975-2980

> Ramos-Onsins SE, Rozas J (2002) Statistical properties of new neutrality tests against population growth. Mol Biol Evol 19:2092-2100

Roberts CM (1997) Connectivity and management of Caribbean coral reefs. Science 278:1454-1457

- Rocha LA, Robertson DR, Roman J, Bowen BW (2005) Ecological speciation in tropical reef fishes. Proc R Soc Lond B Biol Sci 272:573-579

- Rocha LA, Rocha CR, Robertson DR, Bowen BW (2008) Comparative phylogeography of Atlantic reef fishes indicates both origin and accumulation of diversity in the Caribbean. BMC Evol Biol 8:157

Rogers AR (1995) Genetic evidence for a Pleistocene population explosion. Evolution 49:608-615

Rogers AR, Harpending H (1992) Population growth makes waves in the distribution of pairwise genetic differences. Mol Biol Evol 9:552-569

> Ronquist F, Huelsenbeck JP (2003) MrBayes 3: Bayesian phylogenetic inference under mixed models. Bioinformatics 19:1572-1574

> Rosenberg NA, Nordborg M (2002) Genealogical trees, coalescent theory and the analysis of genetic polymorphisms. Nat Rev Genet 3:380-390

> Rosenthal R, Rubin DB (1984) Multiple contrasts and ordered Bonferroni procedures. J Educ Psychol 76: 1028-1034

Scheiner SM (1993) Genetics and evolution of phenotypic plasticity. Annu Rev Ecol Syst 24:35-68

> Schirripa MJ, Colbert JJ (2006) Interannual changes in sablefish (Anoplopoma fimbria) recruitment in relation to oceanographic conditions within the California Current System. Fish Oceanogr 15:25-36

Schuler W, Roper T (1992) Responses to warning coloration in avian predators. Adv Stud Behav 21:111-146

Seehausen O, van Alphen J (1998) The effect of male coloration on female mate choice in closely related Lake Victoria cichlids (Haplochromis nyererei complex). Behav Ecol Sociobiol 42:1-8

Shanks AL (2009) Pelagic larval duration and dispersal distance revisited. Biol Bull (Woods Hole) 216:373-385

Shulman M, Bermingham E (1995) Early life histories, ocean currents, and the population genetics of Caribbean reef fishes. Evolution 49:897-910

Simpson SD, Yan HY, Wittenrich ML, Meekan MG (2005) Response of embryonic coral reef fishes (Pomacentridae: Amphiprion spp.) to noise. Mar Ecol Prog Ser 287: 201-208

> Smith-Vaniz WF (1972) Two new species of Caribbean deep-dwelling jawfishes (Opistognathus, Opistognathidae). Copeia 48-53

> Stobutzki IC, Bellwood DR (1997) Sustained swimming abilities of the late pelagic stages of coral reef fishes. Mar Ecol Prog Ser 149:35-41

Swofford D (2003) PAUP*. Phylogenetic analysis using parsimony ( ${ }^{*}$ and other methods). Version $4 \mathrm{~b} 10$. Sinauer Associates, Sunderland, MA 
Tajima F (1989) Statistical method for testing the neutral mutation hypothesis by DNA polymorphism. Genetics 123:585-595

Taylor MS, Hellberg ME (2003) Genetic evidence for local retention of pelagic larvae in a Caribbean reef fish. Science 299:107-109

Taylor MS, Hellberg ME (2006) Comparative phylogeography in a genus of coral reef fishes: biogeographic and genetic concordance in the Caribbean. Mol Ecol 15: 695-707

Trakhtenbrot A, Nathan R, Perry G, Richardson DM (2005) The importance of long-distance dispersal in biodiversity conservation. Divers Distrib 11:173-181

Wabnitz C, Taylor M, Green E, Razak T (2003) From ocean to aquarium: the global trade in marine ornamental species. UNEP-WCMC, Cambridge

Walder RE (1975) Geographic distribution in the yellowhead jawfish, Opistognathus aurifrons (Perciformes: Opistognathidae). MS thesis, Florida Atlantic University, Boca Raton, FL

Waples R (1995) Evolutionarily significant units and the conservation of biological diversity under the Endangered Species Act. In: Nielsen JL (ed) Evolution and the aquatic ecosystem: defining unique units in population

Editorial responsibility: Hans Heinrich Janssen, Oldendorf/Luhe, Germany conservation. American Fisheries Society, Bethesda, MD, p 8-27

Ward R, Zemlak T, Innes B, Last P, Hebert P (2005) DNA barcoding Australia's fish species. Philos Trans R Soc Lond B Biol Sci 360:1847-1857

Warner RR (1997) Evolutionary ecology: how to reconcile pelagic dispersal with local adaptation. Coral Reefs 16: S115-S120

Watanabe M, Iwashita M, Ishii M, Kurachi Y, Kawakami A, Kondo S, Okada N (2006) Spot pattern of leopard Danio is caused by mutation in the zebrafish connexin 41.8 gene. EMBO Rep 7:893-897

Weersing K, Toonen RJ (2009) Population genetics, larval dispersal, and connectivity in marine systems. Mar Ecol Prog Ser 393:1-12

Werner T, Koshikawa S, Williams TM, Carroll SB (2010) Generation of a novel wing colour pattern by the Wingless morphogen. Nature 464:1143-1148

Wittenrich ML (2007) The complete illustrated breeder's guide to marine aquarium fishes. T.F.H. Publications, Neptune City, NJ

Young FA (1982) The yellowhead jawfish: breeding the marine mouthbrooder in captivity. Freshw Mar Aquar 4: $50-51$

Submitted: September 16, 2010; Accepted: October 5, 2011

Proofs received from author(s): December 22, 2011 